\title{
Environmental Aspects of Resource-Saving Cement Technology
}

\author{
Olga MIRYUK* \\ Rudny Industrial Institute, 111500, Rudny, Kostanay Region, Kazakhstan
}

\begin{abstract}
The article outlines the main problems that the cement industry causes to the environment. Authors propose technological solutions aimed at resource-saving in cement production and environmental protection. The research is devoted to low-energy cement obtained on the basis of waste from processing skarn-magnetite ores. The characteristics of the composition and properties of the technogenic material are given. The authors have justified the feasibility of using skarn-magnetite ore enrichment waste as a part of a cement raw material mixture. The possibility of changing the composition of cement by reducing the energy-intensive alite phase is demonstrated. Technological and heat engineering calculations confirming the reduction of natural mineral raw materials and fuel costs in the production of cement were carried out. The processes of hydration of the developed cements have been investigated. A method for accelerating the hardening of low-base cements due to mechanical activation, the introduction of mineral additives and a modifier is proposed. The research revealed construction and technological advantages of the developed cements, which exhibit increased resistance during operation in an aggressive environment. Physical and mechanical tests of concretes made of low-base cement were carried out. The possibility of reducing the temperature during the heat treatment of concrete is proved. Physical and mechanical tests of concretes made of low-base cement were carried out. The paper presents environmental benefits of the developed cement technology.
\end{abstract}

Keywords - Low-base clinker; hardening; sintering temperature; technogenic materials

\section{INTRODUCTION}

The socio-economic development of modern society is closely related with the environmental situation and depends on nature for the use of materials, fuel and electricity.

The construction industry develops dynamically. The construction sector occupies a leading position among other industries in terms of the use of natural resources. Intensive extraction and processing of raw materials for the production of building materials leads to irreplaceable depletion of the earth interior and pollution of the human habitat.

Resource-saving problems determine a high relevance of the environmental assessment of construction technologies. Effective solution of environmental problems is an important criterion for the advancement of technological methods.

Concrete is the main material used in modern construction. Due to having many remarkable qualities, concrete is an energy-intensive material. For the production of $1 \mathrm{~m}^{3}$ of concrete, an average of $90 \mathrm{~kg}$ of conventional fuel is consumed [1]. The energy intensity of concrete largely depends on the binder, as evidenced by the structure of energy costs for the production of concrete: $67-70 \%$ is accounted for by cement. The reduction of the consumption of carbon-

* Corresponding author.

E-mail address: psm58@mail.ru 
containing fuels in cement production is a serious challenge [2]-[7]. This is achieved by developing low-energy technologies and improving the composition of binders.

Cement production plays an ambiguous role in shaping the environmental situation. On the one hand, the cement industry is a source of environmental pollution due to dust and gas emissions. On the other hand, cement production acts as an ecological reserve of society. Numerous industrial wastes are widely used for the production of cement [8]-[13]. Cement is the basis of effective materials that ensure the durability of structures and the safety of human life.

Resource saving is an important condition for the effective development of cement production and use. Therefore, the development of binders with a low carbon footprint based on the use of man-made raw materials is very important.

The purpose of the research is the development of low-energy cement from the waste produced in the processing of skarn-magnetite ores.

\section{Methods AND Methodology}

The world largest deposits of skarn-magnetite ores are located in Kazakhstan. The annual processing of ore at processing plants reaches about 30 million tons. At the first stage of processing of skarn-magnetite ores, more than 4 million tons of dry magnetic separation tailings (hereinafter referred to as DMS) are released annually.

The DMS waste is a dry red mixture of particles with a proportion of up to $25 \mathrm{~mm}$. The chemical composition of the DMS tailings is presented, wt.\%: $\mathrm{SiO}_{2} 40-45 ; \mathrm{Al}_{2} \mathrm{O}_{3} 10-12$; $\mathrm{Fe}_{2} \mathrm{O}_{3} 16-18$; $\mathrm{CaO} 12-13 ; \mathrm{MgO} 5-6$; $\mathrm{S} 2-5 ; \mathrm{R}_{2} \mathrm{O} 2-4$; loss on calcination 3-6. Waste contains modifying substances, wt.\%: $\mathrm{TiO}_{2} 0.50-0.53 ; \mathrm{P}_{2} \mathrm{O}_{5} \quad 0.25-0.30 ; \mathrm{MnO} 0.35-0.40 ; \mathrm{V}_{2} \mathrm{O}_{5} 0.04$ 0.06; Cu 0.04-0.05.

An important characteristic of ore enriching waste is mineral composition, which determines the nature of technological transformations of the raw material mass. The mineral basis of DMS tailings is composed of silicates of various structures, chemical activity and thermal stability, wt.\%: pyroxenes 20-25; epidote 10-13; feldspars 8-12; chlorites 7-10; scapolite 8-11; garnets 7-12; amphiboles 7-14. The waste also contains minerals, wt.\%: pyrite 4-8; calcite 4-7; magnetite $3-4$. The radiation and environmental safety of DMS tailings is confirmed by the following indicators: low specific effective activity of radionuclides (53-55 Bq/kg), no toxic emissions, and low volatility of heavy metals.

Waste of DMS was used as a component of raw mixtures to obtain cement clinker. Raw mixtures contained limestone, aluminosilicate and ferrous components. In the traditional raw material mixture, loams were used as an aluminosilicate component, and pyrite cinders were introduced as a ferrous component. DMS waste in the raw mixture allows you to replace loam and pyrite cinders. Composition of raw mixtures was calculated according to the generally accepted method. To adjust a siliceous modulus of raw mixtures, overburden flask was added.

Raw mixtures were prepared by co-grinding components to a specific surface area of $280-300 \mathrm{~m}^{2} / \mathrm{kg}$. Raw mixtures were moulded in the form of briquettes (diameter $-20 \mathrm{~mm}$, height $-30 \mathrm{~mm}$ ) and fired in a laboratory furnace at a temperature of $1350-1450{ }^{\circ} \mathrm{C}$ to produce clinker. Cements were obtained by grinding synthesized cement clinker with the addition of gypsum rock and mineral additives.

Theoretical heat consumption for physical and chemical transformations in the raw mixture was calculated in order to determine the effect of DMS waste on cement clinker synthesis.

Construction and technological properties of cement made from technogenic raw materials were evaluated when testing fine-ground binders and concrete based on them. Mechanical 
activation of cements was carried out in an «Emax» activator mill.

Differential thermal and X-ray phase analysis was used to identify clinkers and hydrated cement compositions. The structure of the cement stone was studied by electron microscopy.

The following abbreviations are used in the article:

- DMS - dry magnetic separation;

- SC - saturation coefficient;

- PC - Portland cement;

- FPC - fine-ground Portland cement;

- FLC - fine-ground low-basic cement.

\section{RESULTS}

\subsection{Influence of skarn-magnetite ore dressing waste on cement clinker formation processes}

The silicate base of the mineral composition, the content of clinker-forming oxides, the presence of non-carbonate lime, the presence of alloying and modifying elements precluded the possibility and feasibility of using DMS tailings in the production of Portland cement clinker [14].

The composition of cement clinkers is evaluated by the value of the saturation coefficient (SC), which characterizes the degree of binding of silica with calcium oxide, the ratio between the main phases of alite $\mathrm{C}_{3} \mathrm{~S}$ and belite $\mathrm{C}_{2} \mathrm{~S}$. Traditional cement clinker is characterized by high basicity and $\mathrm{SC}=0.89-0.93$; the content of alite is $50-60 \%$ and belite is $20-25 \%$. Significant savings in fuel and energy resources are achieved by reducing the basicity of Portland cement clinker and by reducing the energy-intensive phase of alite in the clinker to $30-40 \%$. When producing low-base clinkers with $\mathrm{SC}=0.70-0.80$, the heat consumption for their formation processes is reduced by 10-12\% [15]. However, slow hardening of the material hinders the use of low-base cements that contain an increased amount of belite. A number of technological solutions have been proposed to increase the hydraulic activity of cements [15]-[19]. An effective and affordable method involves a targeted selection of raw materials with a high reactivity [16]-[18]. The chemical and mineral content of the DMS tailings meets these requirements. Studies of clinkers of various basicities obtained using DMS waste have confirmed that a decrease in SC to 0.73 practically does not reduce the design strength of cements.

When switching to low-base clinkers, the proportion of calcium carbonate - the most energy-intensive raw material component - decreases. The introduction of DMS tailings that contain non-carbonate calcium minerals into the raw mix saves limestone (Table 1). The specific consumption of limestone is reduced by almost $122.8 \mathrm{~kg} / \mathrm{t}$ of clinker, or by $10 \%$ (Table 2).

The reduction of the share of the carbonate component, as well as the exclusion of clay hydroaluminosilicates from the rawmix contribute to a reduction in the specific consumption of dry rawmix by $66 \mathrm{~kg} / \mathrm{t}$ of clinker and a reduction in the material consumption of production by $4 \%$ (Table 2). At the same time, $411 \mathrm{~kg}$ of natural raw materials are saved, the extraction and processing of which requires significant energy costs and creates environmental pressures in the region in which the extraction and processing occurs.

The decarbonization process is the most energy-intensive - the decomposition of $1 \mathrm{~kg}$ of $\mathrm{CaCO}_{3}$ requires $1780 \mathrm{~kJ}$. Reduction of the proportion of limestone mixed with DMS waste reduces the thermal cost of decarbonization by $14 \%$. The absence of a clay component in the rawmix containing the DMS waste eliminates the cost of dehydration of minerals; the savings reach $138 \mathrm{~kJ} / \mathrm{kg}$ per clinker. Low-temperature interactions in the fired mixture containing 
waste are associated with the transformations of $\mathrm{FeS}_{2}, \mathrm{Fe}_{3} \mathrm{O}_{4}$. A significant part $(28.8 \%)$ of the heat of exothermic processes is the heat release during the oxidation of pyrite $\mathrm{FeS}_{2}$. The combination of these factors reduces the thermal effect of clinker formation of low-base clinker based on DMS tailings by $33.7 \%$.

To determine the fuel economy, a calculation was made for the main consumption items of the heat balance of the rotary kiln (Table 3).

TABLE 1. INFLUENCE OF THE COMPOSITION OF THE RAWMIX ON THE THERMAL EFFECT OF CLINKER FORMATION

\begin{tabular}{|c|c|c|}
\hline \multirow{2}{*}{ Indicators } & \multicolumn{2}{|c|}{ Main characteristics of the rawmix } \\
\hline & $\mathrm{SC}=0.80$ & $\mathrm{SC}=0.91$ \\
\hline \multicolumn{3}{|l|}{ Main components of the rawmix, $\%$} \\
\hline - limestone & 71.43 & 76.40 \\
\hline - DMS tailings & 20.35 & - \\
\hline - shale & - & 21.96 \\
\hline \multicolumn{3}{|l|}{ Content in the mixture, $\%$ : } \\
\hline$-\mathrm{CaCO}_{3}$ & 70.09 & 77.81 \\
\hline$-\mathrm{MgCO}_{3}$ & 1.50 & 2.09 \\
\hline - pyrite $\mathrm{FeS}_{2}$ & 1.63 & - \\
\hline - hydration water & - & 1.13 \\
\hline Dry raw mixture consumption, $\mathrm{kg} / \mathrm{kg}$ of the clinker & 1.456 & 1.522 \\
\hline Sintering temperature, ${ }^{\circ} \mathrm{C}$ & 1350 & 1450 \\
\hline Carbon dioxide from raw material, $\mathrm{kg} / \mathrm{t}$ of the clinker & 446 & 505 \\
\hline \multicolumn{3}{|l|}{ Heat from endothermic processes, $\mathrm{kJ} / \mathrm{kg}$ of the clinker: } \\
\hline - decarbonisation & 1848 & 2152 \\
\hline - dehydration of clay minerals & - & 138 \\
\hline \multicolumn{3}{|l|}{ Heat of exothermic processes, $\mathrm{kJ} / \mathrm{kg}$ of clinker: } \\
\hline - formation of clinker phases & 518 & 479 \\
\hline - pyrite oxidation & 199 & - \\
\hline Thermal effect of clinker formation, $\mathrm{kJ} / \mathrm{kg}$ of clinker & 1340 & 2020 \\
\hline
\end{tabular}

TABle 2. SAVING RAW MATERIALS WHEN USING DMS TAILINGS FOR CLINKER PRODUCTION

\begin{tabular}{llll}
\hline \multirow{2}{*}{ Raw materials } & \multicolumn{2}{l}{$\begin{array}{l}\text { Specific consumption of raw materials, } \\
\mathrm{kg} / \mathrm{t} \text { per clinker }\end{array}$} & $\begin{array}{l}\text { Material savings, } \mathrm{kg} / \mathrm{t} \\
\text { of low-base clinker }\end{array}$ \\
\cline { 2 - 3 } & $\mathrm{SC}=0.80$ & $\mathrm{SC}=0.91$ & 122.8 \\
\hline Limestone & 1040.0 & 1162.8 & 288.0 \\
Shale & - & 288.8 & 23.4 \\
Pyrite stubs & - & 23.4 & -71.9 \\
Overburden & 119.7 & 47.8 & -296.3 \\
DMS Tails & 296.3 & - & 66.0 \\
Rawmix & 1456 & 1522 & \\
\hline
\end{tabular}


TABLE 3. Fuel ECONOMY WHEN FIRING A LOW-BASE MiXTURE WITH DMS WASTE

\begin{tabular}{|c|c|c|c|c|c|}
\hline \multirow[t]{2}{*}{ Heat balance items } & \multicolumn{2}{|c|}{$\begin{array}{l}\text { Heat consumption, } \\
\mathrm{kJ} / \mathrm{kg} \text { per clinker }\end{array}$} & \multicolumn{2}{|c|}{$\begin{array}{l}\text { Nominal } \\
\text { fuel consumption, } \\
\mathrm{kg} / \mathrm{t} \text { per clinker }\end{array}$} & \multirow[t]{2}{*}{$\begin{array}{l}\text { Nominal } \\
\text { fuel saving, } \mathrm{kg} / \mathrm{t} \\
\text { - per clinker }\end{array}$} \\
\hline & $\mathrm{SC}=0.80$ & $\mathrm{SC}=0.91$ & $\mathrm{SC}=0.80$ & $\mathrm{SC}=0.91$ & \\
\hline Thermal effect of clinker formation & 1340 & 2020 & 45.6 & 68.7 & 23.1 \\
\hline Moisture evaporation & 1747 & 2435 & 59.4 & 82.8 & 23.4 \\
\hline Waste gas losses & 715 & 953 & 24.3 & 32.4 & 8.1 \\
\hline Losses through the kiln body & 592 & 680 & 20.1 & 23.1 & 3.0 \\
\hline Total & 4394 & 6088 & 149.4 & 207.0 & 57.6 \\
\hline
\end{tabular}

A decrease in the clinker synthesis temperature by $100{ }^{\circ} \mathrm{C}$ is accompanied by a reduction in heat loss through the rotary kiln body by $13 \%$ and with waste gases by $25 \%$. Reducing moisture content of low-basic sludge due to plastic clay replacement with hydraulically inert waste decreases heat consumption for moisture evaporation by $28 \%$. When firing low-base clinker in a rotary kiln, the specific fuel consumption is reduced by $28 \%$.

\subsection{Effect of mechanical activation on hydration and hardening of low-basic cement obtained using ore dressing wastes}

Heat treatment significantly accelerates the process of hardening concrete. The effectiveness of the thermal effect depends on the composition of the cement. The use of cements with mineral additives significantly reduces the consumption of clinker - the most energy-intensive component of cement. For example, when using Portland cement, the consumption of clinker per $1 \mathrm{~m}^{3}$ of concrete with a strength of $30 \mathrm{MPa}$ is $290-350 \mathrm{~kg}$, and when using slag-Portland cement it is $165-235 \mathrm{~kg}$. Heat treatment of products is the most energy-intensive stage of concrete technology. To reduce heat costs during concrete hardening, plasticizing additives are used. In most cases, plasticizers are introduced into the concrete mixture. It is effective to introduce plasticizing additives when grinding cement with mineral additives. This technological technique is implemented in the production of binders of low water demand or nano-cement and is recommended for cements with a high alite content [20], [21].

Fine-ground cements of various basicities have been studied. These were obtained by grinding clinker with dihydrous gypsum and a C-3 modifier in a laboratory mill-activator 'Emax'. The concentration of the modifier selected during preliminary experiments was $1.5 \%$ by weight of cement. The cement was ground to a specific surface area of $550 \pm 10 \mathrm{~m}^{2} / \mathrm{kg}$. The modifier, which intensifies the process of clinker grinding, ensured the achievement of a high dispersion without increasing the duration of grinding (Fig. 1). 


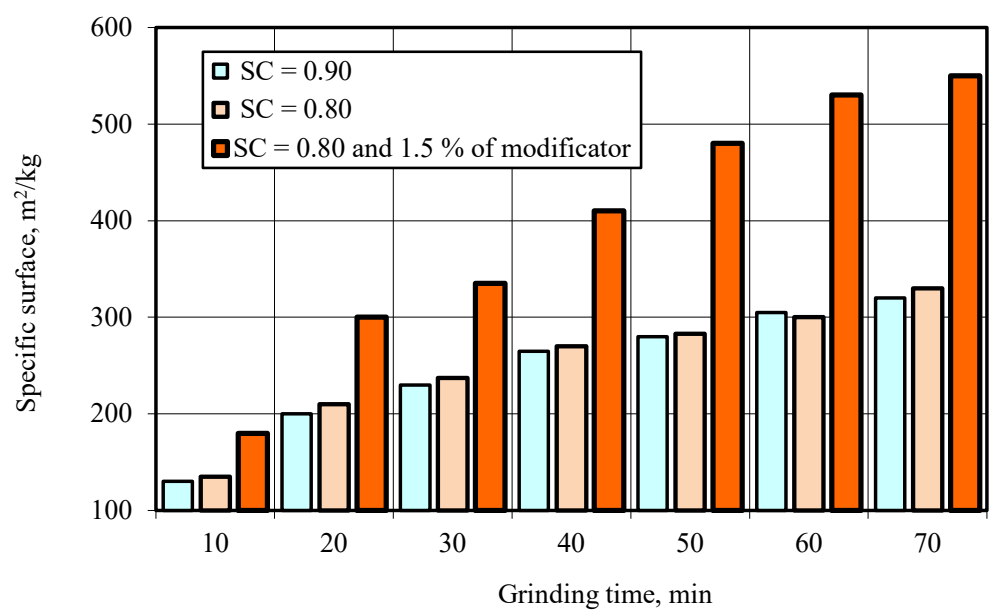

Fig. 1. Influence of clinker composition on cement grinding.

When the clinker is being finely ground, mechanical activation processes take place. The rupture of a solid body is accompanied by the formation of pitting defects and dislocations. Optimization of the grinding conditions is provided by the adsorption action of the modifier - a surfactant and a high level of closed and evenly distributed porosity of the clinker obtained using the DMS tailings. The modifier introduced during grinding promotes microencapsulation of active surfaces and the formation of organomineral complexes on the periphery of cement microflocules. The high content of belite does not complicate the grinding of low-base cement due to the increased grinding capacity of the clinker from waste, as well as the intensifying effect of the $\mathrm{C}-3$ modifier. The efficiency of the modifier increases when grinding clinkers with high structural defects, and the energy efficiency of grinding, the kinetics of the process and the parameters of the grain composition of cement are determined by the heterogeneity of the crystal structure and clinker minerals. The increased porosity of the clinkers under study extends the induction period of crack growth, and significantly increases the effect of the modifier on the yield of the average fraction of 5-30 microns.

The improvement of the grinding capacity, the increase in the proportion of fine particles in the finely ground low-base cements can be attributed to the heterogeneity of the physical and mechanical properties of the crystalline phases. Numerous hard-to-grind belite particles, which have an increased abrasive capacity, perform the function of micro-grinding bodies, provide fine grinding and mechanical activation of large $\mathrm{C}_{3} \mathrm{~S}$ alite crystals. This is beneficial both for the grinding process and for the mechanical activation of the clinker phases. The effectiveness of the combination of different materials in terms of grinding capacity is confirmed during grinding of a mixture of clinkers.

Fine grinding of low-base cements with a modifier increases the early strength of the stone by 2.5-4.0 times (Table 4). The maximum increase in the strength of cement is marked for the composition by the lowest saturation coefficient $(\mathrm{SC}=0.70)$. At the age of 28 days of hardening, the strength indicators of low-base cements increased by $45-65 \%$. At all times of hardening, fine-ground modified cements with $\mathrm{SC}=0.75-0.80$ are not inferior or superior in strength to conventional ground cement with $\mathrm{SC}=0.90$.

Significant rates of hardening of low-base cements are due to the combined influence of several factors. First, the predominance of particles up to 30 microns in size, optimal for hydration, while reducing the water demand of cement from $25.25 \%$ to $21.50 \%$. A special 
role belongs to alite, which retains its activity in finely ground modified low-base cement (Table 4).

The composition of hydrated cement was investigated using differential thermal and X-ray phase analysis methods.

The hydration activity of $\mathrm{C}_{3} \mathrm{~S}$ in high-alite fine-ground cement is reduced due to the low water content of the neoplasms as a result of a decrease in the water-binding ratio. The discrepancy between the low degree of hydration and the high strength of cement stone can be explained by the morphology of hydrate crystals.

The high activity of alite in low-base cement is provided, in our opinion, by the fine dispersion of $\mathrm{C}_{3} \mathrm{~S}$ particles and their relatively limited amount. Slowly hydrating grains of belite, like a micro-filler, evenly surround the individual particles of alite, push them apart and contribute to the expansion of the space where the products of hydration of alite are located. The released portlandite $\mathrm{Ca}(\mathrm{OH})_{2}$ initiates the reaction of belite with water, the products of which adsorb calcium ions from the supersaturated liquid phase. This ensures the high hydration activity of $\mathrm{C}_{3} \mathrm{~S}$. The hydration activity of belite increases independently of the basicity of fine-ground cement.

TABle 4. INFLUENCE OF GRINDING CONDITIONS ON THE PROPERTIES OF CEMENT OF DifFERENT BASICITY

\begin{tabular}{|c|c|c|c|c|c|c|c|}
\hline \multirow{3}{*}{$\mathrm{SC}$} & \multirow{2}{*}{\multicolumn{3}{|c|}{$\begin{array}{l}\text { Compressive strength, } \mathrm{MPa} \text {, } \\
\text { of samples } 2 \times 2 \times 2 \mathrm{~cm} \text { in age, day }\end{array}$}} & \multicolumn{4}{|c|}{ Degree of hydration, $\%$, age, day } \\
\hline & & & & \multicolumn{2}{|c|}{ alite $\mathrm{C}_{3} \mathrm{~S}$} & \multicolumn{2}{|c|}{ belite $\mathrm{C}_{2} \mathrm{~S}$} \\
\hline & 1 & 3 & 28 & 1 & 28 & 1 & 28 \\
\hline \multicolumn{8}{|c|}{ Grinding with the C-3 modifier to a specific surface area of $550 \pm 10 \mathrm{~m}^{2} / \mathrm{kg}$} \\
\hline 0.70 & 12 & 30 & 87 & 22 & 83 & 4 & 33 \\
\hline 0.75 & 55 & 78 & 136 & 20 & 68 & 6 & 40 \\
\hline 0.80 & 76 & 107 & 142 & 21 & 73 & 9 & 41 \\
\hline 0.90 & 106 & 136 & 168 & 14 & 62 & 9 & 28 \\
\hline \multicolumn{8}{|c|}{ Conventional grinding to a specific surface area of $300 \pm 10 \mathrm{~m}^{2} / \mathrm{kg}$} \\
\hline 0.70 & 3 & 11 & 60 & 20 & 93 & 2 & 26 \\
\hline 0.75 & 21 & 32 & 83 & 22 & 85 & 4 & 35 \\
\hline 0.80 & 29 & 51 & 85 & 29 & 82 & 6 & 37 \\
\hline 0.90 & 48 & 71 & 112 & 21 & 70 & 7 & 24 \\
\hline
\end{tabular}

The high strength of the cement stone is determined by the formation of a low-porosity defect-free structure (Fig. 2). Due to the dense packing of the poly-granular particles of the dispersed phase, the distance between the individual grains is minimized. Further compaction of the structure and increasing the strength of the cement stone is facilitated by the close adhesion and contact interaction of sharp-angled particles formed during the grinding of large clear crystals of clinker phases. The zonal structure of halite crystals in the studied low-base clinkers predetermined the formation of particles with different $\mathrm{CaO}$ ratios: $\mathrm{SiO}_{2}$, when they are hydrated, calcium hydrosilicates of different basicity are formed. Hydrates, formed at low water consumption exhibit increased astringency thus providing high strength of the stone.

At the next stage, the influence of mineral additives on the properties of low-base cement is investigated. When grinding, $20-50 \%$ of additives of various composition and origin (thermal energy ash, DMS tailings, glass powder) were introduced simultaneously with $2 \%$ of the modifier. The cements were ground to a specific surface area of $600 \pm 10 \mathrm{~m}^{2} / \mathrm{kg}$. 

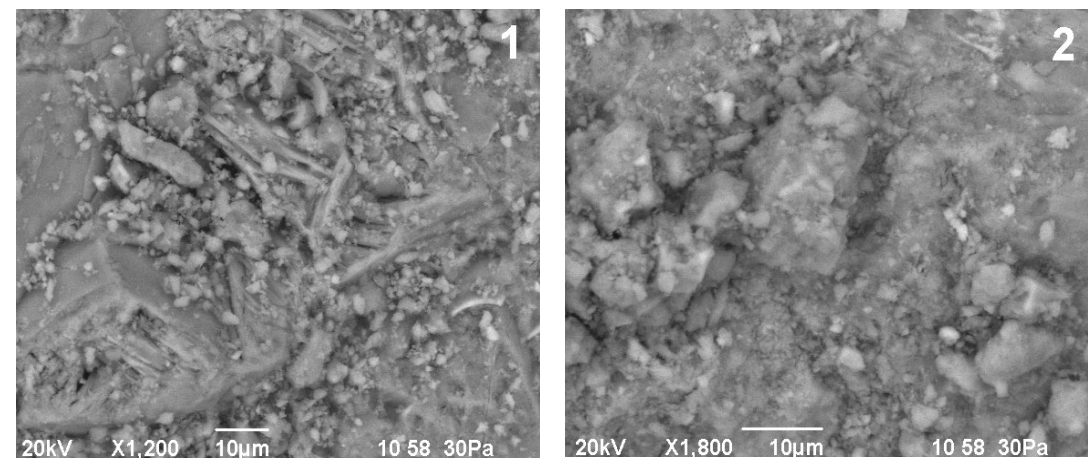

1 - Low- basic cement, $\mathrm{SC}=0.80$ and $1.5 \%$ of modificator; 2 - Portland cement, $\mathrm{SC}=0.90$

Fig. 2. Microstructure of cement stone.

The test results showed the feasibility of limiting the content of mineral additives to $30 \%$. The increased proportion of the mineral component slows down the rate of hardening and reduces the strength of the stone. The greatest strength indicators are achieved in the presence of a combined additive in the cement (DMS tailings and glass powder).

\subsection{Study of the effect of cement composition on fine-grained concrete hardening}

Further studies were carried out on fine-grained concrete. The increased cement consumption characteristic of such concrete allows us to illustrate the influence of the composition and properties of the binder on the quality of the composite material. Concrete mixtures were prepared from binders of various compositions (Table 5) and quartz sand with a fineness modulus of 2.5. The strength characteristics of concrete were determined on samples of $4 \times 4 \times 16 \mathrm{~cm}$ in size, compacted by vibration. The study of rheological characteristics showed an increased sensitivity of concrete mixtures containing modified binders to changes in the water content. There was an increase in the diameter of the spreading cone by 1.5-2.5 times, and a decrease in water separation. The lowest water demand is characterized by concrete mixtures made of low-base cement.

TABle 5. Properties of Binders AND CONCRETE MiXtures.

\begin{tabular}{|c|c|c|c|c|c|c|}
\hline \multirow[b]{2}{*}{ Binder } & \multicolumn{3}{|c|}{ Material composition of the binder, $\%$} & \multirow{2}{*}{$\begin{array}{l}\text { Specific } \\
\text { surface } \\
\text { area, } \mathrm{m}^{2} / \mathrm{kg}\end{array}$} & \multirow{2}{*}{$\begin{array}{l}\text { Water/ } \\
\text { cement }\end{array}$} & \multirow{2}{*}{$\begin{array}{l}\text { Diameter of the } \\
\text { spreading cone of } \\
\text { concrete mixes, mm }\end{array}$} \\
\hline & $\begin{array}{l}\text { low-base } \\
\text { cement }\end{array}$ & $\begin{array}{l}\text { portland } \\
\text { cement }\end{array}$ & $\begin{array}{l}\text { supplement C- } \\
3\end{array}$ & & & \\
\hline \multirow{3}{*}{ FLC } & \multirow{3}{*}{100} & \multirow{3}{*}{0} & \multirow{3}{*}{2} & \multirow{3}{*}{590} & 0.35 & 194 \\
\hline & & & & & 0.45 & 315 \\
\hline & & & & & 0.55 & 350 \\
\hline \multirow{3}{*}{$\mathrm{FPC}$} & \multirow{3}{*}{0} & \multirow{3}{*}{100} & \multirow{3}{*}{2} & \multirow{3}{*}{585} & 0.35 & 180 \\
\hline & & & & & 0.45 & 285 \\
\hline & & & & & 0.55 & 340 \\
\hline \multirow{3}{*}{$\mathrm{PC}$} & \multirow{3}{*}{0} & \multirow{3}{*}{100} & \multirow{3}{*}{0} & \multirow{3}{*}{320} & 0.35 & 108 \\
\hline & & & & & 0.45 & 136 \\
\hline & & & & & 0.55 & 230 \\
\hline
\end{tabular}


To evaluate the strength properties, the following concrete ratio was used: cement and sand ratio of 1:3. Water/binder at the diameter of the spreading cone of the concrete mixture 105-110 mm: 0.32 - FLC; 0.33 - FPC; 0.42 - PC. Concrete samples were stored in water at room temperature. A comparison of the test results (Fig. 3) shows the effectiveness of fine grinding of cements with a modifier. The rate of concrete hardening from low-base cement at an early age exceeds the control indicators. The increase in the strength of concrete on thinground low-base cement compared to the strength of concrete from Portland cement (PC) is $65 \%$ ( 1 day), $50 \%$ (3 and 7 days), $34 \%$ (28 days).

Heat and moisture treatment of concrete was carried out in a laboratory steaming chamber at temperatures of $50{ }^{\circ} \mathrm{C}, 70{ }^{\circ} \mathrm{C}$ and $90{ }^{\circ} \mathrm{C}$. The duration of isothermal heating of concrete samples was 4, 6 and 8 hours.

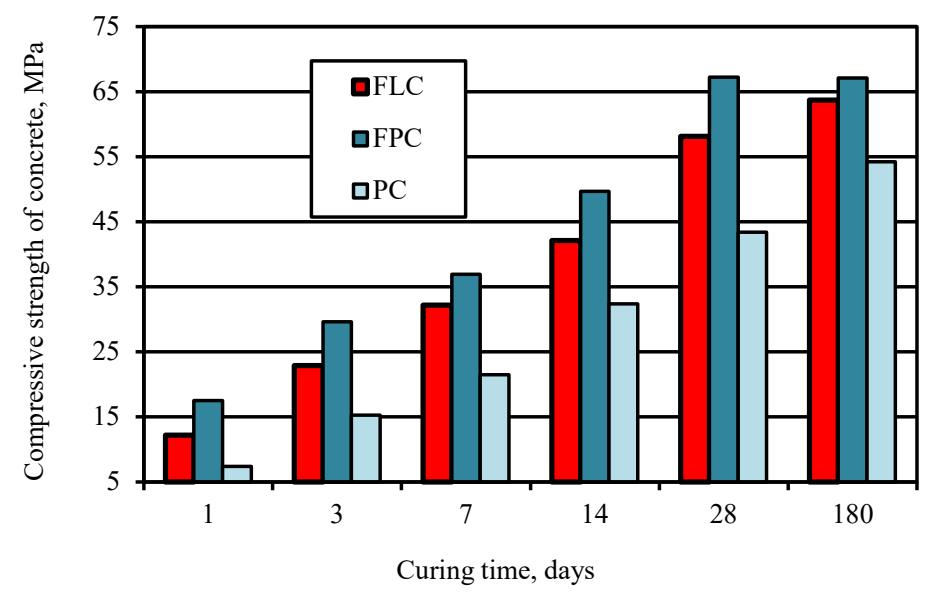

Fig. 3. Influence of binder type on the hardening kinetics of fine-grained concrete.

The strength of concrete made of finely ground, low-base cement is 1.5-2.2 times higher than that of concrete made of similar cement of conventional grinding. To obtain high-strength concrete from finely ground low-base cements after heat treatment, a temperature of $70{ }^{\circ} \mathrm{C}$ is required. Concrete made of ordinary cement with mineral additives are steamed at a temperature of $90{ }^{\circ} \mathrm{C}$. Concrete made of modified low-base cement of fine grinding is characterized by intensive hardening during heat and moisture treatment and an increase in strength after steaming by $60-70 \%$, in comparison with Portland cement. Consequently, the modified fine-ground low-base cement (FLC) obtained by using DMS tailings is a full-fledged substitute for Portland cement, surpassing it in strength at all times of hardening. The cement showed resistance to alternating wetting and drying (the coefficient of air resistance after 100 test cycles is 1.08-1.22), to the action of sulphate aggression (the coefficient of resistance in a $5 \% \mathrm{Na}_{2} \mathrm{SO}_{4}$ solution by 180 days is $0.94-1.12$ ).

\subsection{Environmental benefits of low-basic cement from technogenic raw materials}

For modern production, the problems of economic efficiency and environmental protection are no longer alternative. Utility criteria gain importance by comparing the environmental burden of producing a product and its need for society.

A serious environmental problem of the clinker firing process is the emissions of various gaseous substances, among which nitrogen, sulphur and carbon oxides are common. 
According to [3], [5], and [7], of the 20 billion tons of $\mathrm{CO}_{2}$ released annually as a result of human activity, the cement industry accounts for $5 \%$. The reduction of the carbonate component in low-base charges with DMS tailings results in a $12 \%$ reduction in carbon dioxide emissions (Table 1). In addition, the $\mathrm{CO}_{2}$ output in the combustion products is reduced because of the fuel consumption reduction. Low-temperature sintering of clinkers with reduced SC values reduces the $\mathrm{CO}_{2}$ output from the fuel by $3.5 \%$. Reducing the maximum firing temperature of clinker based on man-made raw materials reduces the emission of nitrogen oxides formed during the combustion of gas in the furnace. According to [2], [4], and [6], when the sintering temperature decreases by $100{ }^{\circ} \mathrm{C}$ for low-base clinker, the degree of interaction of nitrogen with oxygen from the air in the fuel flare decreases, as a result of which the emission of nitrogen oxides is reduced by 1.5 times.

Environmental benefits of using skarn-magnetite ore processing waste to produce low-basic cement are shown in Table 6.

\section{TABLE 6. ENVIRONMENTAL BENEFITS OF LOW-BASIC CEMENT BASED ON TECHNOGENIC RAW MATERIALS}

\begin{tabular}{llll}
\hline & Low-basic cement & $\begin{array}{l}\text { Portland cement } \\
\text { from traditional } \\
\text { from ore dressing } \\
\text { waste } \mathrm{SC}=0.80\end{array}$ & $\begin{array}{l}\text { raw materials } \\
\mathrm{SC}=0.91\end{array}$ \\
& & \\
&
\end{tabular}

Consumption of
natural raw
materials, $\mathrm{kg} / \mathrm{t}$ of
clinker

1. Conservation of natural resources and fertile land areas.

clinker

2. Reduction of waste dumps of associated rocks formed during raw materials extraction.

3. Reduction of harmful emissions during raw materials deposits development.

Content of a
carbonate
component
in the raw mixture,

1. Conservation of natural resources.

2. Reduction of the energy-intensive component.

3. Reduction of $\mathrm{CO}_{2}$ emissions into the atmosphere.

1. Saving thermal energy and natural fuel as a

Heat of exothermic processes, $\mathrm{kJ} / \mathrm{kg}$ 717 479 of clinker valuable raw material for the chemical industry.

2. Reduction of $\mathrm{CO}_{2}$ emissions into the atmosphere.

\begin{tabular}{|c|c|}
\hline $\begin{array}{l}\text { Nominal fuel } \\
\text { consumption for } \\
\text { clinker firing, } \mathrm{kg} / \mathrm{t} \text { of } \\
\text { clinker }\end{array}$ & 149.4 \\
\hline $\begin{array}{l}\text { Clinker dust content } \\
\text { (particles less than } \\
0.63 \mathrm{~mm} \text { in size), } \%\end{array}$ & $20-25$ \\
\hline $\begin{array}{l}\text { Carbon dioxide } \\
\text { emissions, } \mathrm{kg} / \mathrm{t} \text { of } \\
\text { clinker }\end{array}$ & 727 \\
\hline $\begin{array}{l}\text { Coefficient of } \\
\text { cement stone } \\
\text { resistance to sulfate } \\
\text { corrosion }\end{array}$ & 1.03 \\
\hline
\end{tabular}

\section{Conservation of fossil fuels. \\ 2. Reducing harmful impact on the environment during the extraction of fuel. \\ 3. Reducing greenhouse gas emissions into the atmosphere.}

1. Reduction of atmospheric pollution sources.

2. Reduction of raw materials and fuel resources losses spent for clinker production.

\section{Reducing the probability of "greenhouse} effect".

1. Reducing negative impact of corrosion products on the environment.

2. Improving reliability of protective functions of concrete structures that prevent the spread of harmful substances in the environment. 
The gases $\mathrm{SO}_{2}$ and $\mathrm{SO}_{3}$ released during the oxidation of pyrite actively interact with $\mathrm{CaCO}_{3}$ and $\mathrm{CaO}$ to form $\mathrm{CaSO}_{4}$. Some of the sulphur oxides react with the alkalis introduced by the DMS tailings. The formed alkaline sulphates circulate in the furnace so that in high temperature zones they sublimate, and in low temperature zones they condense on the raw material particles. The results of production tests indicate that clinker retains up to $50 \%$ of the $\mathrm{SO}_{3}$ concentration in the raw mixture. Due to the removal of sulphur compounds from the furnace in condensed form, $\mathrm{CO}_{2}$ emissions from the firing of waste mixtures are negligible. The average daily $\mathrm{SO}_{2}$ content in the waste gases during clinker firing on a conveyor machine is $0.02-0.03 \mathrm{mg} / \mathrm{m}^{3}$ and does not exceed the permissible limits.

The ecological balance depends on the concentration of aerosols (dust) in the atmosphere. An important advantage of raw materials mixtures containing ore dressing waste is the reduction of dust removal. The absence of clinker dusting was noted during the firing of experimental batches of clinker, which corresponds to the data [16], [18], according to which the granulometry of the clinker improves when firing low-base mixtures. This is shown in an increase in the amount of the fraction size of $20-100 \mathrm{~mm}$ by $30-40 \%$ and a decrease in dust particles and the complete elimination of clinker dusting.

The use of DMS waste provides resource-saving technologies for low-basic cement. The technogenic component makes it possible to replace a significant part of natural raw materials.

Fuel and energy costs reduction is achieved by decreasing the thermal effect of low-basic clinker formation, exothermic processes in a mixture with ore dressing waste, and influence of alloying elements in DMS tailings on sintering and grinding capacity of clinker.

Improvement of technological processes for the production of cement is accompanied by reduction in gaseous and dust-like emissions into the environment.

Features of low-basic cement composition ensure the durability of construction products under aggressive influence.

When making decisions on the feasibility of using man-made raw materials in the production of cement, the economic aspect is often considered the main one. However, environmental problems are becoming of paramount importance, and attempts to delay finding solutions will entail disproportionately large costs.

\section{Conclusion}

Technological solutions to environmental problems of cement production has been proposed. A cement technology with a low «carbon footprint» has been developed, which provides for the use of large-tonnage waste of skarn-magnetite ore dressing.

Polymineral composition of ore dressing wastes makes it possible to minimize the share of energy-intensive alite phase in cement clinker. Low-basic clinker made from technogenic raw materials, compared with traditional Portland cement clinker, is characterized by $28 \%$ reduction in consumption of natural raw materials and a decrease in carbonate component proportion by $10 \%$.

When firing low-basic clinker from technogenic raw materials, the equivalent fuel saving is $58 \mathrm{~kg} / \mathrm{t}$ of clinker.

Reduction in the content of a carbonate component in the raw mixture and in fuel consumption is accompanied by a decrease in greenhouse gas emissions, including carbon dioxide, by $16 \%$ when firing low-basic clinker.

High hydration activity of low-basic cement is provided by the nature of clinker synthesis processes, mechanical activation in the presence of chemical and mineral additives. Low-basic cement, which is not inferior in mechanical properties to ordinary Portland cement, 
provides increased resistance of building products in aggressive environments. Increasing concrete durability guarantees protective functions of concrete structures and reduces the risk of negative effects of corrosion products on the environment.

\section{ACKNOWLEDGEMENT}

This research is funded by the Science Committee of the Ministry of Education and Science of the Republic of Kazakhstan (Grant No. AP08856219).

\section{REFERENCES}

[1] Jani Y., Hogland W. Waste Glass in the Production of Cement and Concrete - A Review. Journal of Environmental Chemical Engineering 2014:2(3):1767-1775. https://doi.org/10.1016/j.jece.2014.03.016

[2] Environment U.N., Scrivener K.L., John V.M., Gartner E.M. Eco-efficient cements: Potential economically viable solutions for a low- $\mathrm{CO}_{2}$ cement-based materials industry. Cement and Concrete Research 2018:114:2-26. https://doi.org/10.1016/j.cemconres.2018.03.015

[3] Maddalena R., Roberts J. J., Hamilton A. Can Portland cement be replaced by low-carbon alternative materials? A study on the thermal properties and carbon emissions of innovative cements. Journal of Cleaner Production 2018:186:933-942. https://doi.org/10.1016/j.jclepro.2018.02.138

[4] Grege-Staltmane E. Development of Evaluation Methodology for Carbon Dioxide Emissions in Production Processes. Environmental and Climate Technologies 2013:3:31-34. https://doi.org/10.7250/iscect.2013.006

[5] Gong Y., Fang Y. Preparation of belite cement from stockpiled high-carbon fly ash using granule-hydrothermal synthesis method. Construction and Building Materials 2016:111:175-181. https://doi.org/10.1016/j.conbuildmat.2016.02.043

[6] Miller S. A., John V. M., Pacca S. A., Horvath A. Carbon dioxide reduction potential in the global cement industry by 2050. Cement and Concrete Research 2018:114:115-124. https://doi.org/10.1016/j.cemconres.2017.08.026

[7] Gao T., Shen L., Shen M., Liu L., Chen F. Analysis of material flow and consumption in cement production process. Journal of Cleaner Production 2016:112:553-565. https://doi.org/10.1016/j.jclepro.2015.08.054

[8] Bisikirske D., Blumberga D., Vasarevicius S., Skripkiunas G. Multicriteria Analysis of Glass Waste Application. Environmental and Climate Technologies 2019:23:152-167. https://doi.org/10.2478/rtuect-2019-0011

[9] Koumpouri D., Angelopoulos G.N. Effect of boron waste and boric acid addition on the production of low energy belite cement. Cement and Concrete Composites 2016:68:1-8. https://doi.org/10.1016/j.cemconcomp.2015.12.009

[10] Ávalos-Rendóna T. L., Pastén Chelala E. A., Mendoza Escobedo C. J., Figueroa I. A., Lara H. V., Palacios-Romerod L. M. Synthesis of belite cements at low temperature from silica fume and natural commercial zeolite. Materials Science and Engineering:B 2018:229:79-85. https://doi.org/10.1016/j.mseb.2017.12.020

[11] Mazouzi W., Kacimi L., Cyr M., Clastres P. Properties of low temperature belite cements made from aluminosilicate wastes by hydrothermal method. Cement and Concrete Composites 2014:53:170-177. https://doi.org/10.1016/j.cemconcomp.2014.07.001

[12] Dahhou M., Barbach R., Moussaouiti M. E. Synthesis and characterization of belite-rich cement by exploiting alumina sludge. KSCE Journal of Civil Engineering 2019:23:1150-1158. https://doi.org/10.1007/s12205-019-0178-Z

[13] Sobolev K., Turker P., Soboleva S., Iscioglu G. Utilization of waste glass in ECO-cement: Strength properties and microstructural observations. Waste Management 2007:27:971-976. https://doi.org/10.1016/j.wasman.2006.07.014

[14] Miryuk O. A. Thermal transformations of the technogenic component of the cement raw material mixture. Ecology and Industry of Russia 2020:24:36-41. https://doi.org/10.18412/1816-0395-2020-4-36-41

[15] Kacimi L., Simon-Masseron A., Salem S., Ghomari A., Derriche Z. Synthesis of belite cement clinker of high hydraulic reactivity. Cement and Concrete Research 2009:39:559-565. https://doi.org/10.1016/j.cemconres.2009.02.004

[16] Koga G.Y., Comperat P., Albert B., Roche V., Nogueira R.P. Effect of endogenous chloride contamination on the electrochemical and hydration responses of reinforced belite-ye'elimite-ferrite (BYF) cement mortars. Cement and Concrete Research 2019:122:212-226. https://doi.org/10.1016/j.cemconres.2019.04.022

[17] Gartner E., Sui T. Alternative cement clinkers. Cement and Concrete Research 2018:114:27-39. https://doi.org/10.1016/j.cemconres.2017.02.002

[18] Wang P., Li N., Xu L. Hydration evolution and compressive strength of calcium sulphoaluminate cement constantly cured over the temperature range of 0 to $80{ }^{\circ} \mathrm{C}$. Cement and Concrete Research 2017:100:203-213. https://doi.org/10.1016/j.cemconres.2017.05.025

[19] Maheswaran S., Kalaiselvam S., Palani G. S., Sasmal S. Investigations on the early hydration properties of synthesized $\beta$-belites blended cement pastes. Journal of Thermal Analysis and Calorimetry 2016:125:53-64. https://doi.org/10.1007/s10973-016-5386-X 
[20] Singh N. B., Kalra M., Saxena S. K. Nanoscience of Cement and Concrete. Materials Today: Proceedings 2017:4:5478-5487. https://doi.org/10.1016/j.matpr.2017.06.003

[21] Suthatip S., Kittipong K., Suwimol A. Synthesis of belite cement from nano-silica extracted from two rice husk ashes. Journal of Environmental Management 2017:190:53-60. https://doi.org/10.1016/j.jenvman.2016.12.016 